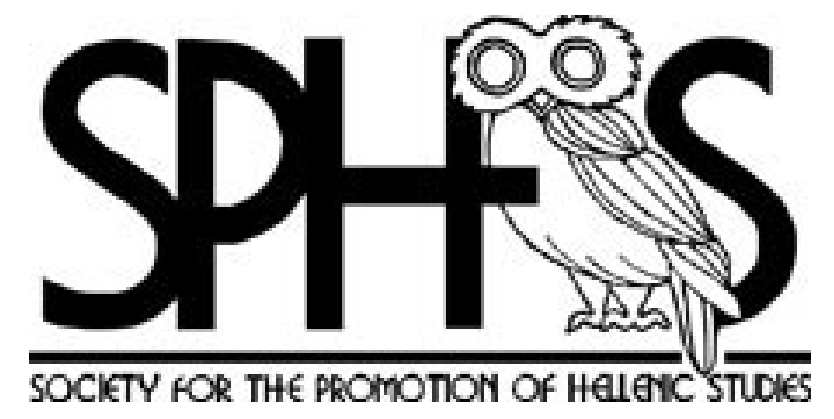

Selected Vase-Fragments from the Acropolis of Athens--I

Author(s): G. C. Richards

Source: The Journal of Hellenic Studies, Vol. 13 (1892 - 1893), pp. 281-292

Published by: The Society for the Promotion of Hellenic Studies

Stable URL: http://www.jstor.org/stable/623908

Accessed: 12/12/2014 08:11

Your use of the JSTOR archive indicates your acceptance of the Terms \& Conditions of Use, available at

http://www.jstor.org/page/info/about/policies/terms.jsp

JSTOR is a not-for-profit service that helps scholars, researchers, and students discover, use, and build upon a wide range of content in a trusted digital archive. We use information technology and tools to increase productivity and facilitate new forms of scholarship. For more information about JSTOR, please contact support@jstor.org.

The Society for the Promotion of Hellenic Studies is collaborating with JSTOR to digitize, preserve and extend access to The Journal of Hellenic Studies. 


\title{
SELECTED VASE-FRAGMENTS FROM THE ACROPOLIS OF ATHENS.-I.
}

\author{
[Plates XI., XII.]
}

THE vase-fragments from the Acropolis of Athens, here published for the first time (Plates XI. and XII.), with the exception of one which appeared long ago in Benndorf's Griechische und Sicilische Vasenbilder (Pl. XI. 6), are of the greatest interest, not merely as problems of restoration difficult enough to satisfy the most ardent enthusiast for Greek ceramography, but because of the important position they occupy among the vase-finds of the Acropolis, which have already revolutionized vase chronology, and to the careful study of which we may look for much more light in the future. They are perhaps the most important fragments in the blackfigured style which have hitherto remained unpublished, and as the majority of these older fragments are either hasty and careless productions or less interesting in subject than the less numerous but more uniformly important remains of red-figured works, it is the more desirable that they should become known to the learned world. Several of the fragments were drawn for the Hellenic Society some years ago, and when I had opportunity of access to the Museum of the Acropolis two years back, it was my pleasant duty to search for other portions of the original vases, with a view to a more complete publication. I was successful in bringing together several that are now published, the drawings being executed by the practised hand of $\mathbf{M}$. Gilliéron, who had been commissioned with the earlier work. It is therefore hardly necessary to state that these drawings are scrupulously faithful, especially as Mr. Ernest Gardner has been kind enough to supervise their execution. For the permission to publish them I am much indebted to $\mathbf{M}$. Kavvadias, the General Ephor of Antiquities. The fragments belonged to three or possibly four vases. Plate XI. Fig. 1 gives seven fragments of the outside scenes of a large kylix ${ }^{1}$; the two fragments below (Fig. 2) probably belong to the same work, and if so, owing to the thickness of the clay, to the upper rather than to the lower frieze, but it is also possible that they may be part of a different vase. On this point I am scarcely able to

1 The remains of several b. f. kylikes of large dimensions have been found on the Acropolis, cp. the one whose outside scenes are a chariot-

H.S.-VOL. XIII. race and a Gigantomachy, not yet completely published. 
pronounce, not having myself seen them, and I can only accept the opinion of those who have brought them into this connexion. Plate XII. Fig. I reproduces seven fragments of a large vase of the shape commonly called Deinos (sometimes 'fussloser Krater' or Holmos), which must have measured about ten inches in diameter from inner rim to inner rim. The first feeling on seeing what is left to us must necessarily be one of disappointment, that so very little remains of what was undoubtedly a magnificent vase. One may conjecture that it rested on a separable stand (perhaps of shape 204 in Furtwängler's Berlin Catalogue), but there are apparently no fragments of anything of the kind; or it may have stood alone like the specimen painted under the horses of a quadriga in the Chariot-race frieze of the François vase. Unlike that however there is here no rim setting off from the body of the vase. Finally Plate XII. Fig. 2 shows an isolated fragment, drawn in the earlier batch, which I was unable to associate with any others. It cannot be certainly assigned to any special vase-form. As the drawings are in each case of the size of the original, measurements are unnecessary. In no case do we find the discolouring produced by fire on several of the Acropolis fragments, but the upper coats of paint are often much worn. Since the vases were broken into so many pieces, it is obviously impossible to obtain information as to the circumstances and locality of the find in each case, nor is it of much consequence, since no one presumably will question the pre-Persian date of the fragments, because one fragment was in the Athenian collections long before the excavations on the $\mathrm{S}$. side of the Parthenon. As it is hardly necessary to maintain by argument the genuine archaism of these vases, we may pass on at once to the detailed description of them.

A.-Plate XI. On the outside of a kylix, which must have been of considerable dimensions, we find the remains of two friezes, the upper doubtless the larger of the two. The colours employed, other than black, are a rich purple and a yellowish white, apparently laid on over black. The incised line is used freely on a black surface, as on the hair and flesh of men ; but on a yellow surface, e.g. the flesh of a woman or a chiton, the inner drawing is rendered with thin streaks of black. Inscriptions are annexed to the figures, some running from right to left, others from left to right, and composed of large letters laid on in broad strokes. These belong to the older Attic alphabet; the aspirate still has the cross-bar at top and bottom, the vertical stroke of rho does not project below the rounded one, the sigma has three strokes but is of rounded formation, while one half-preserved letter is of irregular shape. The whole character of the lettering points to a date as early as or earlier than 550 B.C., and roughly corresponding with that of e.g. the Moschophorus dedication. First let us take the fragments of the upper frieze, which is enclosed by two black lines-one close to the rim of the vessel, the other supporting the feet of the figures represented. The position of the four fragments to the left of the plate in relation to one another is within narrow limits certain. We see walking to left a female figure, the sex being indicated by the yellow slip, which covers the feet. 
The upper fragment shows the back of the head crowned apparently by a sort of high 'polos' suitable to a goddess, indicated by stripes one of which is yellow, while from beneath it the hair falls in a long plait, of which the separate tresses are marked by incised lines on black. She wears a long chiton painted black, on which a scale pattern is traced with the point, the scales being in many cases touched up by spots of purple; the border at the bottom and the sandal straps are also given in purple. At the waist a spot of yellow paint seems to be the end of a girdle, and the hanging end above it scems to be the tip of an ample diplois. To judge from the other inscriptions, we have lost the name of this goddess, as it was probably written vertically to left of her. There are no sufficient data to justify an attribution, as the scales may merely be a form of decoration for the chiton, and it may just as well have been another goddess as Athena or Amphitrite. Immediately following her is the best preserved figure, the bearded and ivy-crowned Dionysos, inscribed $\Delta \iota$ ó $_{\nu \sigma}\left[{ }_{0}\right]$, the upper part of his body being almost entirely preserved. His right arm is bent at the elbow and he holds in his hand the kantharos; in his outstretched left hand is a vine-branch, the grape-bunches being represented by dashes of black enclosed by wavy incised lines and the leaves by purple. The short-sleeved chiton is covered with a yellow slip, aad wavy lines of thin black represent its woollen texture, as do the thin brown lines of the severe red-figured style. The purple himation passes over his left shoulder, and its end is drawn over the left arm. What is most noticeable in the figure is that the face and neck are also painted purple, which seems simply to be done for the sake of variety and contrast of colour (see for this Plate XII. where there is a similar use of purple for the human body). The beard, moustache, hair, eye and ear are rendered by black, and the detail is given by incised lines. The eye 'en face,' 2 with eyebrow indicated, and the ear are very carefully drawn, and the leaves of the ivy wreath are done in purple. The head, drawn with the most refined care, and the attitude remind us of the Dionysos on the oinochoe of Cholchos (Wiener Vorl. Blätter, 1889, i), which however lacks the archaic nä̈vete of this vase and shows the stereotyped woodenness of advanced b.f. vase-painting, or of the head of the seated figure on the plate from Marathon (Ath. Mitth. vol. vii. Pl. III.), which is also apparently a Dionysos. There can be no better sample of early Attic vase-painting at its best than this head. Beneath the vine-branch are the puzzling remains of an inscription, a vertically written $\Gamma$, then after a space for at least four letters a trace of another (? A) on the fragment which bears the feet of the goddess; here the letters seem to turn round in the reverse direction, and finally behind the $\Gamma$ parts of an $E$ and $V$ (the latter joins on to the vine-branch but

2 It has been somewhat absurdly suggested that the eyes of Dionysos on the François vase are intended to express the effect of wine. The double circle with or without indication of the corners is the conventional representation of the male eye at this period. One might as well suggest that a similar reason prompted the rendering of Dionysos' face here in red! 
cannot be part of it), with space beyond for at least one more letter. I must confess myself unable to suggest any probable restoration. In this position the names of Poseidon and Zeus are impossible. An artist's signature here is not very likely, and a combination of meaningless letters, such as occur on later b.f. vases, is not to be thought of, nor the later $\pi i \epsilon \iota \epsilon \hat{v}$. There is also the difficulty of the position of the letters and the improbability that they had reference to the goddess in front.

Behind Dionysos is the vertically written inscription 'A $\phi \rho \circ \delta i[\tau \eta]$ and a small part of a female figure, clad in a purple robe dotted with yellow spots in groups of four, who bears on her left (?) arm, of which the bracelet is indicated by two thin black lines, a little black child holding on by its right band. One thinks at once of the passage in the description of the Chest of

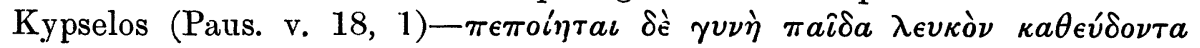

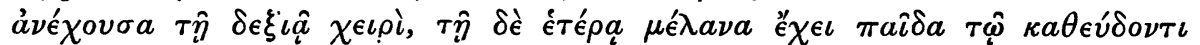

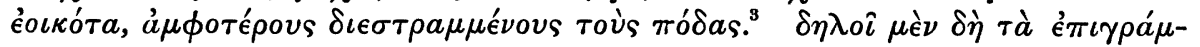

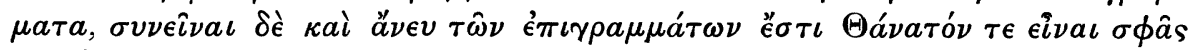

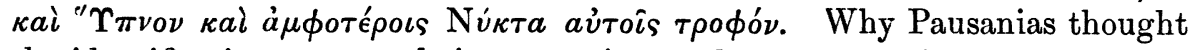
the identification so very obvious, one is at a loss to say; for if he had not mentioned the inscriptions, and particularly if the scene had occurred in the topmost $\chi \omega \dot{\omega} \rho$, one might have been tempted to suppose in the light of this fragment that he was wrong. But, as Brunn has recently pointed out (Griechische Kunstgeschichte, vol. i. p. 174), it is unjustifiable to assume errors in Pausanias' description, unless there be some such sufficient reason as the absence of inscriptions in the original. Here we have only to see one of the common instances of the transference of early art-types from one subject to another. Assuming as one fairly may that the two types were practically identical, one might proceed to argue that, as on the Chest there was a white boy on the right arm of Night, therefore we see here the left arm of Aphrodite, as the boy is black. But apart from the improbability that an early artist, aiming at contrast of colour, would have represented the boy and the arm on which he sat in one colour, such reasoning is rendered impossible by the fact that among the Acropolis vases is a sherd of later date (hitherto unpublished) on which Aphrodite clad in a stately chiton and himation is represented bearing on her elbows two little naked boys both black. Thus I have no doubt we should restore this vase. One may even hazard the suggestion that the difference of colour between the two on the Chest was due to damage or discolouring. Miss Harrison, in a paper read before the Hellenic Society (J.H.S. vol. x. 'Transactions' p. xxxvii.), when dealing with this fragment, 'rejected the interpretation that the child was Eros and maintained that Aphrodite was represented in the more general aspect of Kourotrophos.' Now it is likely that Aphrodite as well as Gê was worshipped at Athens under this title (and probably in the sanctuary of Aphrodite Pandemos, which Paus. i. 22, 3 tells us stood close to that of Gê

\footnotetext{
3 This expression should mean 'splay-footed,' i.e. with the feet twisted unnaturally apart. If so, the point is not illustrated by our vase.
} 
Kourotrophos on the south-west slope of the Acropolis ${ }^{4}$ ), especially as Sophocles is quoted as having addressed her by this name (Athenaeus xiii. 592 A) as did Plato the Comedian; but the child is certainly Eros or rather Himeros, as on the unpublished fragment just alluded to we find on the one side the inscription $\$ O 4 \exists \mathrm{MIH}$, on the other E[POS]. I cannot however see the antagonism between the two facts. These vase-fragments give us the earliest representations of Eros as yet known (see Furtwängler in Roscher's Lexikon, pp. 1349-50); but these little naked puppets are obviously the symbols of a cult, quite distinct from the art-type of the winged boy, which was developed under the influence of lyric poetry. One must think here rather of a primitive worship of natural powers, such as was the cult of Eros at Thespiai, into which this picture of Aphrodite as a mother gives us a glimpse, and put it down to the growing influence of poetry, when the names of Himeros and Eros are added. The two other fragments of this vase are tantalizingly small. On one we see part of the head of a goddess also moving to left (as was Aphrodite probably), who was dressed in the same fashion as Dionysos with chiton in yellow and himation in red, her hair being bound with a stephane, the encircling band in yellow and the fastenings of the back-hair in purple. Behind is an uplifted hand probably belonging to another goddess, the name $\Delta \eta \mu \eta_{\tau} \tau[\rho]$ being written above from right to left. It is also possible that the name belongs to the goddess whose head is preserved. The other fragment shows portions of the legs of two figures. To left is the lower corner of a purple robe ornamented in the same way as that worn by Aphrodite, and a purple boot fastened round the ankle (incised lines on black) with the projecting tongue in front used for pulling the boot on. ${ }^{5}$ As the portion of the leg shown is black, there being no traces of an upper coat of yellow having worn off, and this kind of boot is usually found worn by men, it seems best not to regard this as the leg of Aphrodite in spite of the identity of the dress. In so large a group of figures as that on this vase the same dress might naturally be repeated. The shortness of the chiton also indicates a god as the wearer. Behind comes "A whom remain only a portion of the long chiton (purple with black border enclosed by incised lines) and a foot from which the purple paint of the boot is partly worn away showing a black ground beneath. We see then here a procession of divinities, but it is hardly a profitable subject for discussion to inquire what scene was here represented. Half a dozen might be suggested and really there are no data by which to decide between them.

We now turn to the scanty remains of the lower frieze. In the fragment

4 In this context see the important remarks of Dr. Winter on the early cult of Aphrodite on the Acropolis in his paper on the 'Acropolis Terra-cottas' read before the Berlin Archaeologische Gesellschaft (Berl. Phil. Wochenschrift, Oct. 28, 1893).

5 Scherer has pointed out (Roscher's Lexikon, p. 2400, s.v. Hermes) how this kind of boot worn by other gods and heroes beside Hermes (cp. Theseus on the vase of Taleides) probably suggested the wings on the ankles of the god, which are in later works more appropriately placed behind but on early vases appear in front (cp. Perseus on the Aeginetan lebes, $A . Z$. 1882, pl. 9, and Hermes on the vase of Sophilos Ath. Mitth. 1889.) 
which contained the feet of the first goddess is a portion of a scene to which another fragment fits. Here we see first an arm painted yellow, grasping a spear, and a kneeling female figure to right, naked except for a purple himation falling down her back and doubled over the left arm, which is extended in supplication. She is bcing seized by the right wrist by a man, of whom only part of the purple himation and the left arm are preserved. The hair of the woman is confined by a purple stephane, and incised lines in two places show the way in which it is arranged as it falls down the back. The inner drawing of the body is rendered in thin black lines. Happily we are left in no doubt as to the scene represented, as the name ' $\sigma \mu \eta^{\prime} \nu \eta$ is added, and one calls to mind the amphora from Caere with

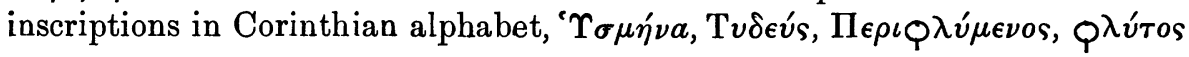
(Wiener V.B. 1889 xi. 4), which apparently represents the same scene. According to the argument to Sophocles' Antigone, Mimnermos was the poetical authority, but doubtless the tale was already told in the lost Thebais how Tydeus surprised Periklymenos (or, according to the argument, Theoklymenos) the Theban with Ismene and slew her. The paramour seems to make his escape on the Corinthian vase, though as he was the slayer of Parthenopaios, one of the seven (Paus. ix. 18, 6, quoting the Thebais), one may conjecture that the object of Tydeus was to take vengeance, and only disappointed fury prompted him to slay Ismene. We can have little doubt that the same story was depicted here. Ismene has fallen on her knees imploring mercy with uplifted hand, as in the Caere amphora, but the rough grasp of Tydeus seems to show that her appeal will be in vain. Of this frieze there remains only part of a retrograde inscription, under the feet of Artemis, the first letter being probably $M$, the second certainly $E$ and in the third I can only see a $N$, of which the right hasta has been rounded by a careless stroke. If this is so, the fragment should be moved to the extreme

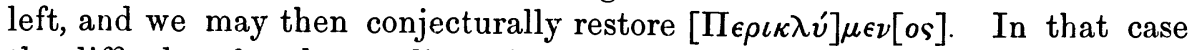
the difficulty of understanding why a woman should be loolding a spear is removed, and this arm will belong to Periklymenos making his escape to left, as in the Caere amphora, and here also with his body painted the colour which is conventionally applied only to women. It is however surely a misconception to ascribe this to a desire on the artist's part to indicate effeminacy, but it is really due, at any rate in the Caere vase, to the artistic aim at contrast of colours. If it be replied that here Ismene and Periklymenos would be next to one another, whereas on the other vase they are divided by the black body of Tydeus, I should say that the dress of Periklymenos himself, if preserved, would in all probability show how a contrast of colour was effected. It only remains to say a word about the two much damaged fragments represented in Fig. 2, as to which I cannot absolutely satisfy myself that they belonged to this vase. We see two female figures in conversation with outstretched arms, one with purple himation (possibly over yellow chiton), the other with the so-called Oriental wings, rendered by a purple patch and then incised lines on black, and a 
purple garment. A piece of a similar wing is all that remains of a lower frieze on the vase of Sophilos. Possibly there were only stylized figures on either side of a handle, which would account for the break in the middle. Of the puzzling objects to the left (spears and shield?) I can give no explanation.

B.-Plate XII. Fig. 2 (to take the less important first) is an isolated fragment of later date, as here we have the open $H$. Beneath a double anthemion and lotus-bud pattern exactly similar to that of the vase of Sophilos, expressed by incised lines with patches of red imposed, is the helmeted head of a warrior, who with right arm drawn back is about to plunge his spear into the body of a foe. Nothing is visible of the latter except a black patch, which might be part of a shield, and a curved object in purple, which was probably some part of the armour. The object in black and purple behind the warrior's head is also of uncertain attribution. Only the eye and nose of the warrior are seen, the nose-flap of the Corinthian helmet not being indicated in a profile view. The helmet is purple; the crest and face are given by incised lines on black, a pattern on the crest being added in white, now barely visible. In the field we read APISTA and HE The latter would naturally be restored " $\mathrm{H} \phi[a \iota \sigma \tau o s]$, which suggests that here is one of the duels of a Gigantomachia. In that struggle Hephaistos is generally represented as taking part, though he has no fixed antagonist. The other word is not likely to be a love-name or an artist's signature, and as Suidas mentions a giant Aristaios, son of Uranos and Gaia, we may restore that name. The nomenclature of the Giants is very shifting, so that the rarity of the name is no objection. It may be added that the Gigantomachia is a subject frequently represented on the Acropolis vases, and seems to have been very common on votive pinakes, where Athena figures laying Enkelados low.

C.-Plate XII. Fig. 1 presents a subject of great interest especially on account of its inscriptions, and both the friezes, which are partially preserved, seem to have been agonistic in character. Round the rim of the vase runs a broad black line, below it a broad red one, and then depending from another black line the pattern, which is invariably just below the junction of neck and body of the 'vasi-a-colonnette' from Caere, and is also common on Attic amphorae and in a similar position on the older hydriae of the metallic shape. It is formed by rows of parallel strokes connected by rounded ones and enclosing alternately a patch of red and black paint. The figures in the upper frieze tread on a black line, which is followed by a red bar, and yet another ornamented with yellow dots. Beneath the second frieze is again a red bar, and below that the black lustrous paint, with which the rest of the vase was probably covered. Three of the fragments are connected, but there are no means of determining the position of the other four. Purple is largely used not merely for garments but to relieve the monotony of black, where the naked body is represented. Thus the body of one hero, who walks with another, is totally 
purple except the hair and beard; and a spot of purple and rosette of dots occur on the thighs of others. ${ }^{6}$ A yellowish-white is also used, for the double flutes of a musician (though not for the $\phi \circ \rho \beta \epsilon i a)$, for one face, for the legs of a horse, and for a peculiar object in the lower frieze. The inner drawing is, except on white, done entirely with incised lines, which render the curling contour of the long hair and the fillets, which bind the head of every figure. The presence of a flute-player suggests athletic contests, and at the extreme left of the illustration stands one of the prizes, a tripod of the usual type, ornamented with red and inscribed $\lambda^{\prime} \beta \eta$ s, which reminds one of the $\theta \hat{a} \kappa o s, i \delta \rho i a, \kappa \rho \eta \dot{\nu} \eta$ and $\beta \omega \mu$ ós of the François vase, or the $\dot{a} \sigma \kappa a ́-$ $\lambda a \beta o s$ of the oinochoe from Loutráki on the Isthmos (Ath. Mitth. 1879

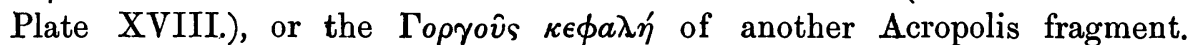
Approaching the tripod are two nude bearded heroes, who are contrasted in colour as described above, except that the left arm of the front one is left black where it crosses the body of the other. Each carries in his left hand a

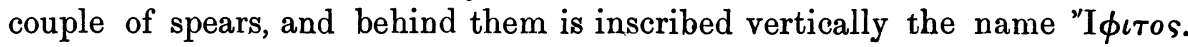
Over the tripod is the right hand and arm of a man who is just about to throw a spear. He has no thong to give it a rotatory motion, but otherwise may be restored conjecturally in the position given in a Panathenaic vase (J.H.S. i. Plate VIII.). Here then was represented one of the contests of the Pentathlon. ${ }^{7}$ Back to back with the first pair is another long-haired and bearded nude warrior, whose face neck and breast are rendered in purple, while the rest of his body except for the rosette on his thigh is black. He is holding a spear in both hands and faces a similar figure, who is apparently stooping and balancing a spear in both hands, preparing for the throw. Behind his shoulder is the point of another spear, and below half the letter $M$, all that remains of a vertically inscribed name. Facing left is a fluteplayer, whose face resembles the others except that it is unbearded. The

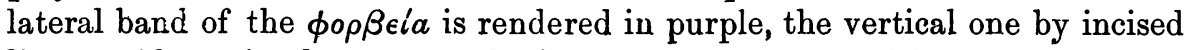
lines. Above is the retrograde inscription $\Phi_{\iota} \lambda o \nu \beta o \nu$ (sic!), the simplest explanation of which is that the final letter is a $n u$ carelessly substituted for a sigma, so that the name is really Philombos. ${ }^{8}$ With this we might compare the name of the dedicator of the Moschophoros, which is written -ovßos. The lower fragment shows a pair of feet emerging from beneath a chiton; these may belong to the flute-player, but on each side is a foot belonging to two other persons, whom it would be difficult to fit into the available space. The elongated foot to right is perhaps that of a wrestler, or it might belong to a man preparing to throw the diskos (as in Gerh. A.V.iv. 270). Behind the flute-player (again vertically written) we read $k A \Gamma$ with an

6 This is not intended to represent tattooing but merely decorative. Compare as an extreme instance of this the Ares on the vase of Cholchos.

7 For a discussion of the Pentathlon see Prof. Gardner's paper in the Hellenic Journal, ad loc. cit.
$8 \mathrm{I}$ do not think it possible that the name is really $\Phi \iota \lambda \delta \nu \in \omega s$, a known Attic name (that of the archon for 527 B.c., as the Constitution of Athens tells us), as $\triangle$ BET (Mon. ix. 55) hardly justifies the assumption of a confusion between Attic and Corinthian epsilon here. The name can hardly be $\Phi \iota \lambda \delta \mu \beta \omega z$. 
additional stroke, which probably belongs to an $A$ or $P$. Behind again are the heads of two bearded and draped figures to left, who would seem to be judges not competitors; one holds a staff and the other holds up his hand as if in astonishment. They seem to be watching some event, perhaps a wrestling match going on before them. Behind the second we read $\Pi \epsilon \rho i \phi a[s]$. Somewhere near this fragment we may place the one figured to the extreme right, in Plate XII., which contains two very similar heads and a portion of a third. The middle one of the three carries a staff, and above is inscribed Фó $\rho[\beta a \varsigma]$ (?). Of the upper frieze there remains only the fragment published by Benndorf, showing a procession to left in the style of the François vase, two or three walking abreast. Of those in front little is left but the heads of the spears they carry, and the three that follow also bear spears. These spear-heads are longer than the others and show the fitting into the shaft; they would seem therefore to be ordinary war-spears, and not the ácó $\nu \tau \iota a$ used for throwing in the Pentathlon. In front of them we read 'A $\sigma \tau \epsilon \rho i \omega \nu$ and behind is an alpha and a trace of another letter, it is uncertain what.

In the lower frieze there was apparently a race or procession of pairs of horses, the outside one ridden by a helmeted warrior carrying two spears, the inside one by a beardless youth. We frequently see on early vases the riders of $\kappa \epsilon ́ \lambda \eta \tau \epsilon s$, and also men riding one horse and leading a second, e.g. the warriors covered by their shields, who appear on 'vasi-a-colonnette.' ${ }^{9}$ Here these two types seem to be combined. Between the two pairs of riders is an object painted white. Its outline is not that of the back of a horse, nor could either of the two persons in front be riding on it, if it were. There is also a pointed object on the surface, which it is difficult to account for. Is this a $\sigma \hat{\eta} \mu a$ or something of the kind, which the riders are passing? On the last fragment are the hind-legs of a pair of horses, differentiated by the colouring white and black and (apparently) the tips of three out of four hoofs of the horses immediately following. The two lines running down into the legs must be the shafts of spears, and, if so, the fragment is part of the same procession rather than part of a chariot-race.

We now turn to see what information the inscriptions can afford us, setting aside the peculiar name Philombos (?), which may be intended for the flute-player. The name of Asterion, an Argonaut, suggests the funeralgames of Pelias, and takes us to the description of that mythic event as represented on the Chest of Kypselos, and to its best-known vase representation, viz. the Amphiaraos vase of Berlin (Mon. x. 4-5, Wiener V.B. 1889 Plate X.). ' Heracles is sitting on a throne,' says Pausanias, ' and there is a female flute-player. Pisos, Asterion, Polydeukes, Admetos and Euphemos are engaged in the race of bigae' (the Amphiaraos vase shows Kastor, Euphemos and Admetos as three of the six competitors in a quadriga race):

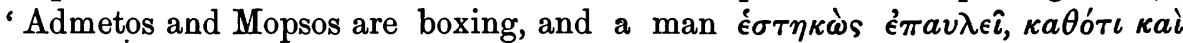

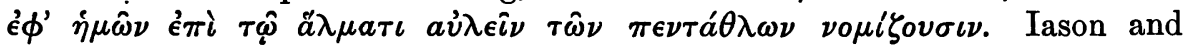
Peleus are wrestling' (in the Amphiaraos vase Peleus and Hippaichmos):

9 Cf. Mon. dell Inst. 1855, pl. 20. 
'Eurybotas is throwing the diskos. The competitors in the foot-race are Meilanion, Neotheus, Phalareus, Argeios and Iphiklos; the latter receives the prize from Akastos. Tripods are placed as prizes for the victors.' Unless Iphiklos is a mistake for Iphitos, which is unlikely, Asterion alone is common to our vase and the Chest. But Phorbas (if the probability of that restoration be allowed) and Periphas were sons of Lapithes and therefore appropriate participants in a Thessalian Agon, and moreover Phorbas, who banished snakes from the island of Rhodes, was famed in myth as a boxer. The initial letter $M$, mentioned above, may be regarded as the beginning of the name Mopsos. Iphitos, son of Naubolos from Phokis, was also an Argonaut. If the figure between the two warriors in the procession is that of a woman, as the drawing of the eye suggests, and if it is not a mere variation of colours, as two horses are drawn of different colours, then who so appropriate here as Atalanta, who according to the common version of the story wrestled with Peleus at these games? ${ }^{10}$ Though she herself is not represented on the Chest, Meilanion is at any rate present. Finally we have the letters $\mathrm{Ka} \pi$ - to complete. No names seem to be available but Kapetos, Kapros and Kapaneus. Kapetos was one of the suitors slain by Oinomaos, and hardly seems likely. There was a historical athlete Kapros, but his date was 215 B.c. It may seem inappropriate to have the presumptuous Argive chieftain, who figures in Theban legend, brought in here, but I can suggest nothing better, and at any rate the painter of the Amphiaraos vase makes Amphiaraos one of the competitors in the chariotrace. This may unly be due to carelessness or it may point to a popular mixture of Theban and Thessalian legends. Enough has been said, I think, to justify one in associating our vase with the representations of the funeralgames of Pelias. But another question may now be propounded. Did not the early vase-painter or decorator regard this myth merely as a framework, the substance of which was filled up by the Olympic Games of his own day? Was there not here a sort of 'contaminatio' between myth and actuality? I -believe this to have been the case with the craftsman who wrought the scene on the Chest of Kypselos. In the first place Herakles, the reputed founder of the Olympic Games, is presiding over the whole, and secondly Pisos son of Perieres, eponymous hero and oekist of Pisa (Paus. vi. 22, 2) is present, and that fact alone must have made the ordinary spectator think of the contest as taking place on the banks of the Kladeos rather than in faraway Iolkos. The Pentathlon too was obviously in the mind of the designer, when he represented three of its five contests, and on our vase probably wrestling and diskos-throwing were represented as well as spear-throwing. Nor can it be doubted that the fame of the Phokian Argonaut was quite overshadowed by that of the great king of Elis of the same name, who set the festival on a firmer basis and obtained a general consent to the sacred truce. Thus we should expect a mixture of the mythical and the real in these

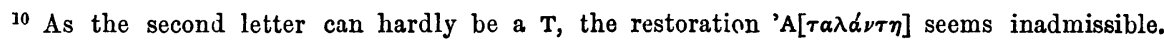

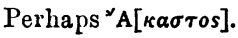


scenes, and thus the associations roused in our minds by the sight of the name Iphitos are perhaps not altogether out of place.

With respect to the inscriptions, the lettering is that of the Old Attic alphabet, except that the four-stroke sigma is used. Similarly in the great amphora found in the Piraeus St. at Athens (Ant. Denkm. Plate 57) we find the four-stroke sigma in the name of Herakles, the three-stroke sigma in that of Nessos, which in true Attic form appears as Néros. Sophilos uses the three-stroke sigma, but reverses it. Perhaps the four-stroke sigma, the Corinthian form written another way up, was more extensively used than we are aware of in early Attic inscriptions. It need not necessarily indicate Ionic influence.

It only remains to say a few words as to style. Plate XJI. Fig. 2 is a type of the developed Attic b.f. style current in the latter half of the sixth century. The kylix Plate XI. is perhaps as fine an instance as we have of early Attic vase-painting. Its author was a better artist than Sophilos and his work seems to have been to him a labour of love. Plate XII. Fig. 1 is on the same stylistic level with the vase of Sophilos, and shows to my mind the strong influence exercised by Corinth on early Attic work. Loeschcke long ago (A.Z. 1876, p. 108) suggested the likelihood that Athenian vase-painters worked from Corinthian patterns. To that view I adhere and believe that the painter of this vase was at any rate strongly under Corinthian influence. It is true that Corinth gave rise to no school of the great art of sculpture, but her influence in the more industrial fields of art in the sixth and even seventh centuries can hardly be exaggerated, and she has justly been called 'the Sidon of Hellas.' Let us take the points of contact between the Amphiaraos vase and our fragments : (1) the pattern alluded to above; (2) the heads are drawn in the same manner, and one notes the stereotyped hair-band and hair outline and the identical rendering of the eye ; (3) the principle of variety produced by a change of colour is strongly exemplified in both, cf. with the horses' legs on our fragment the quadriga of Amphiaraos in his Departure-scene, or the biga on the vase from Loutráki; (4) the corresponding use of the incised line with black and the dark line of paint for the border of white; (5) on the lower frieze of our fragments occurs a flying bird exactly similar to those which fill the spaces between the horsemen on the Amphiaraos vase. These resemblances seem to be sufficient to bear out the above contention. Brunn refused to allow the genuineness of the Amphiaraos vase ${ }^{11}$ as an archaic work, but his view in this respect has been generally rejected, and, since the discovery of the Corinthian votive pinakes, which show points of resemblance in style with our fragments, the archaistic hypothesis with reference to vases that bear Corinthian inscriptions

11 In the continuation of his Probleme 926, Brunn complains that Robert rejects the probable conjecture of Boecklı on Paus. v, 9, 5, of Eे the accepted vase-chronology. That difficulty must howerer be faced. If Boeckh is right, the archaism of the Amphiaraos vase is suspicious. If however other evidence seems to show the vase to be archaic, then the emendation loses its probability. 
292 VASE-FRAGMENTS FROM THE ACROPOLIS OF ATHENS.-I.

has lost all probability. The heads on the top of the handles of Caere 'vasi-a-colonnette' are enlarged specimens of the heads on the pinakes of Penteskuphia. My conviction is that future researches and discoveries will only make us assign a more important place than before to Corinth in the early history of Greek ceramography, and will in particular bring out more clearly the strong influence exercised by Corinthian art on the growing settlement of potters in the Athenian Kerameikos during the sixth century.

G. C. Richards. 


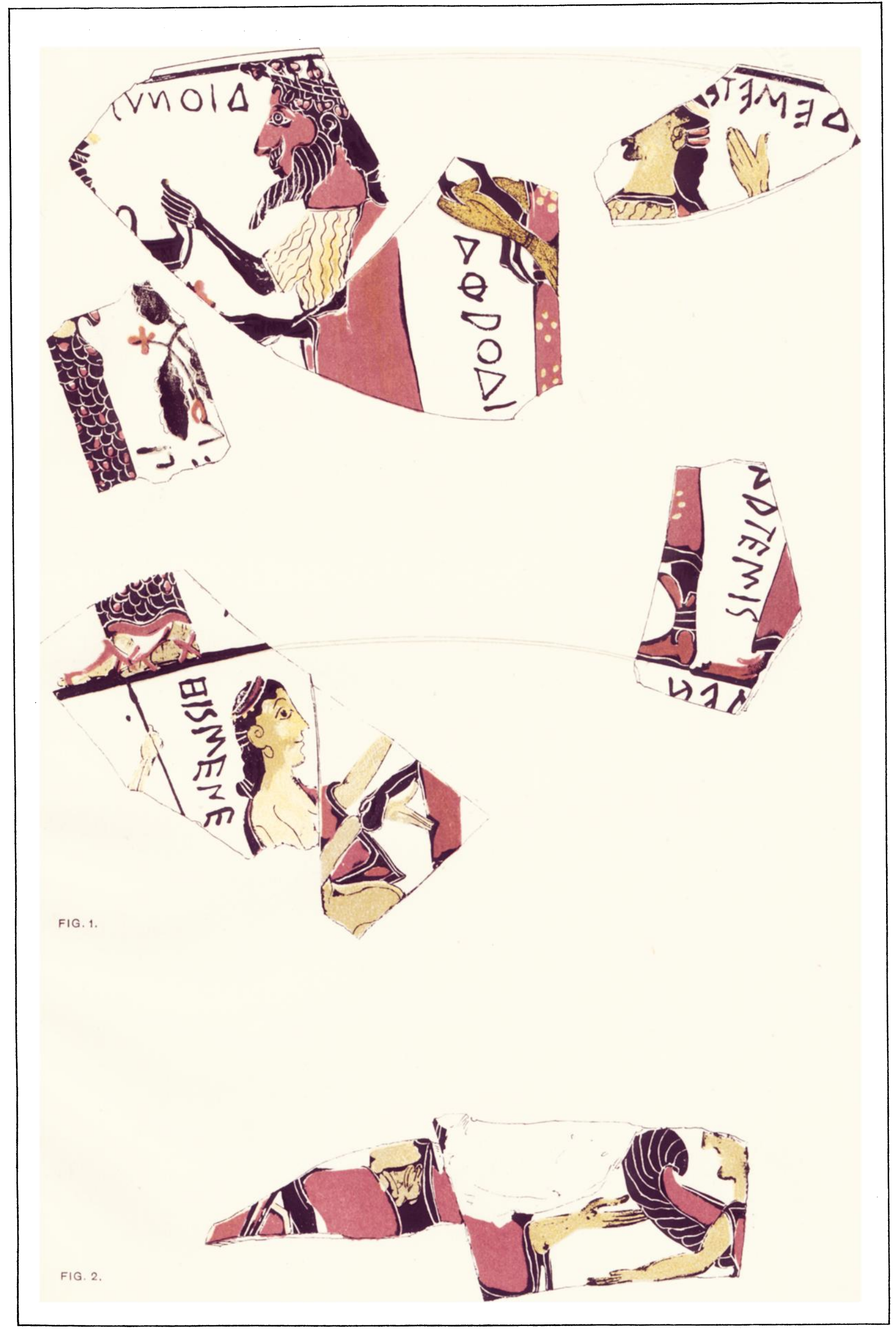

VASE FRAGMENTS FROM THE ACROPQLIS OF ATHENS. 


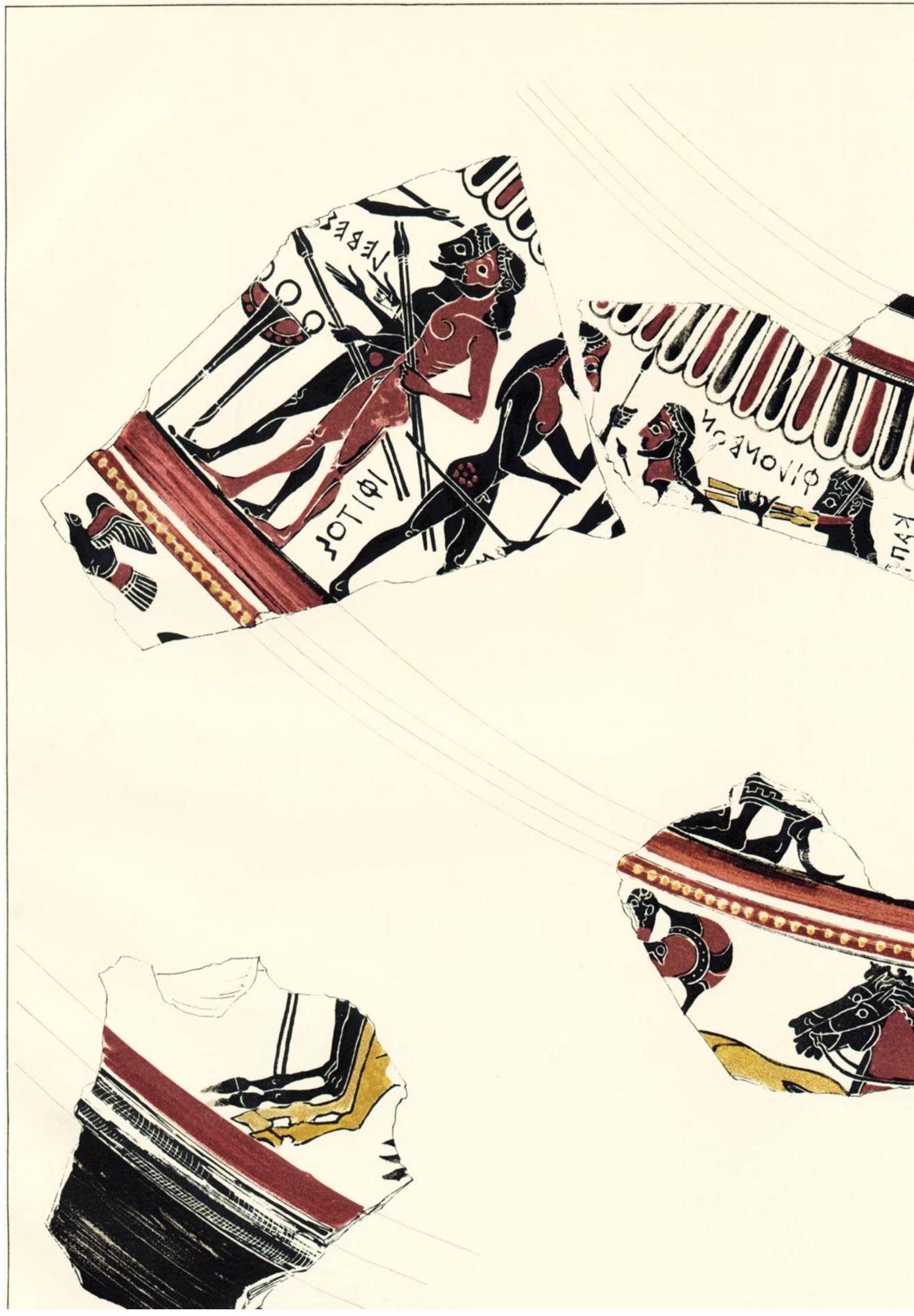

This content downloaded from 128.235.251.160 on Fri, 12 Dec 2014 08:11:46 AM All use subject to JSTOR Terms and Conditions 

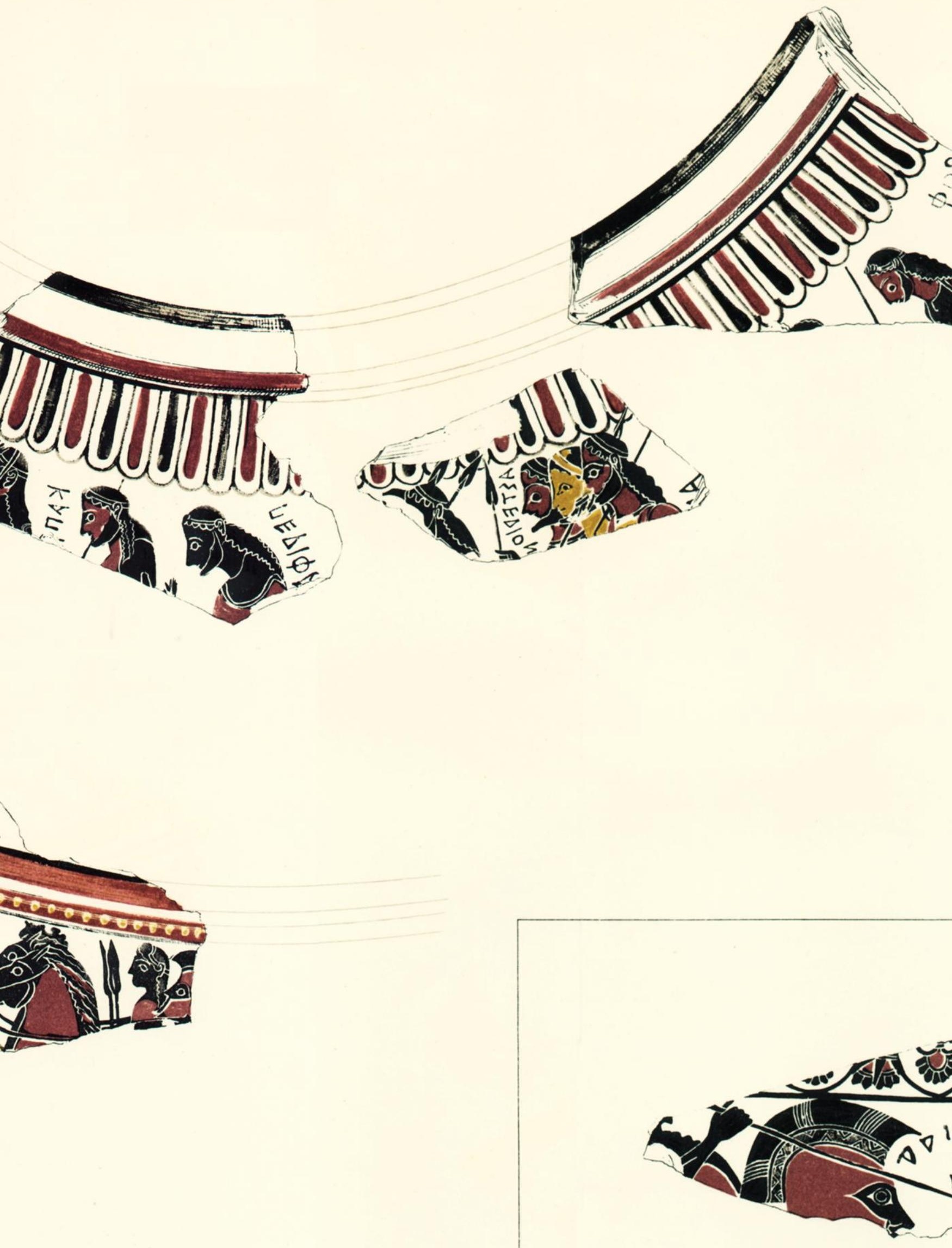


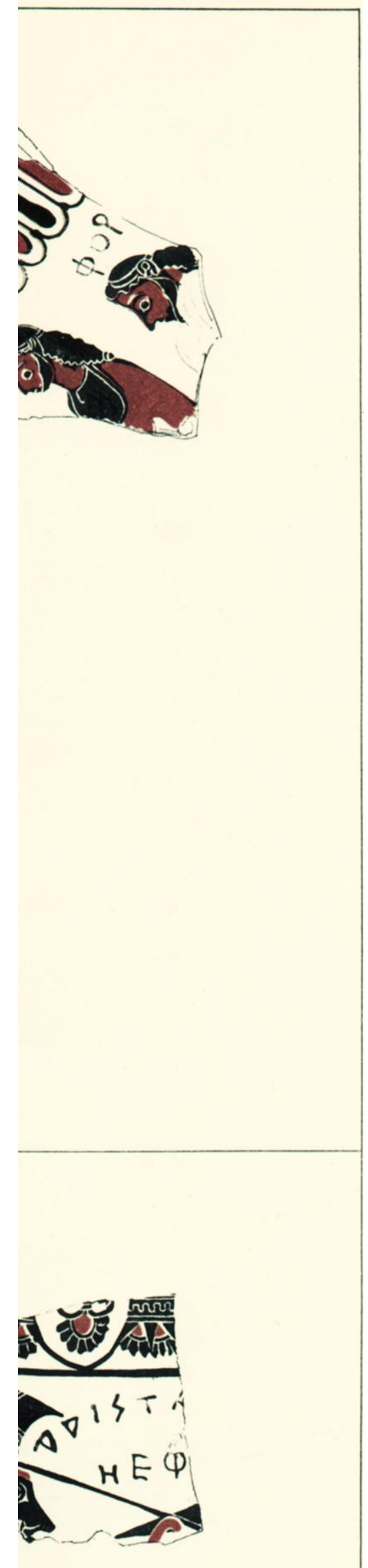

This content downloaded from 128.235.251.160 on Fri, 12 Dec 2014 08:11:46 AM All use subject to JSTOR Terms and Conditions 
FIG. 1. 
FIG. 2.

RAGMENTS FROM THE ACROPOLIS OF ATHENS. 


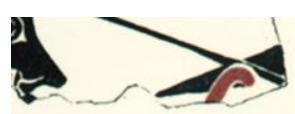

This content downloaded from 128.235.251.160 on Fri, 12 Dec 2014 08:11:46 AM All use subject to JSTOR Terms and Conditions 